\title{
The Influence of Learning Model Oriented Analogy on Material Acid and Based Towards Learning Outcomes
}

\author{
Elsy Indria \\ Department of Chemistry Education, \\ State University of Medan \\ Medan, Indonesia \\ * coresponding author: eindria19@gmail.com
}

\author{
Zainuddin Muchtar \\ Department of Chemistry Education, \\ State University of Medan \\ Medan, Indonesia
}

\author{
Marham Sitorus \\ Department of Chemistry Education, \\ State University of Medan \\ Medan, Indonesia
}

\begin{abstract}
The aims to point out: 1) knowing the effect of the learning model oriented analogy on student learning outcomes; 2 ) knowing the effect of the level of learning motivation taught by the learning model oriented analogy on learning outcomes; 3 ) knowing the interaction between learning models with the level of learning motivation on student learning outcomes; 4) knowing the learning completeness of students who are taught with a FAR learning model oriented analogy with a level of motivation. The study population was all students of class XI MIA SMAN X. The study sample was students of class XI MIA 2 and XI MIA 2 , amounting to 27 students. The research instruments are objective tests of valid and reliable learning outcomes, student learning motivation questionnaire sheets. The analysis technique used is Two Way Anova technique on SPSS 23. The results of the study concluded that: 1) there was no influence between the learning model oriented analogy on student learning outcomes. 2) there is an effect of the level of student motivation that is taught by the FAR analogy oriented learning model. 3) there is no interaction between the two learning models with the level of motivation towards student learning outcomes. 4) the highest student learning completeness is in the process oriented guided inquiry learning (POGIL) model oriented analogy with a high level of learning motivation.

Keywords: model, analogy, motivation, learning outcomes,
\end{abstract} acids and bases

\section{INTRODUCTION}

Education is one important element in improving the quality of human resources because by taking education one can obtain knowledge, experience, and skills through a learning process [1], so to improve human resources must be done to improve the quality of learning. Improving the quality of learning can be done with innovations in learning such as the development of learning media, procurement of laboratory equipment and improving the quality of teachers [2].
The teacher is the spearhead of the success of learning activities in schools that are directly involved in planning and implementing learning activities. The role of the teacher as a facilitator, motivator, and student mentor in improving the ability of students to understand the material well requires the teacher to have the right strategy and use appropriate learning media. But in fact the main problem of learning that is still widely found is the low student learning outcomes. The reason is because the teacher centered learning is still based on teacher-centered learning, where the teacher plays an active role in explaining the concept while the student is passive in accepting the concept. The teacher has implemented discussions in the classroom but is not effective because most students have not been able to understand the material so that it is less motivated.

The factors causing the lack of motivation of students in learning are; 1) Conventional learning methods that tend to be monotonous, where learning is teacher-centered; 2) Lack of use of instructional media due to limited teacher knowledge about learning media; 3) There are subjects that are still considered difficult to understand by students, one of them is chemistry [3].

Chemistry is one part of natural science that is taught at the secondary to tertiary level. One characteristic of chemistry learning is the study at the microscopic level, which includes the structure, dynamics, and transformation of particles of matter, such as atoms, ions, and molecules. Chemistry is a difficult subject because many chemical concepts are abstract [4].

Acids and bases are one of the chemical materials that are required with abstract concepts that cannot be seen with the eyes, but can only be imagined [5]. Acid base learning contains material about the theory of acid base, the nature of acids and bases, the strength of acids and bases and the concept of $\mathrm{pH}$. In 
general, the material learned is memorized and counts that require a high level of understanding.

The main problem of learning that is still widely found is the low student learning outcomes. The reason is because the teacher centered learning is still based on teacher-centered learning, where the teacher plays an active role in explaining the concept while the student is passive in accepting the concept. The teacher has implemented discussions in the classroom but is not effective because most students have not been able to understand the material so that it is less motivated.

Efforts can be made so that students are motivated so that learning outcomes increase is the teacher needs to choose and apply learning models that are able to direct and demand students to form their own knowledge. One learning model that directs students to construct their own knowledge and students become active is Process Oriented Guided Inquiry Learning (POGIL) and Problem Based Learning (PBL).

POGIL is a collaborative learning technique guided inquiry and three-phase learning cycle (exploration of concept discovery, and application) where students are involved in the learning process so that a combination of cooperative learning and guided inquiry in POGIL learning provides opportunities for students to be active in discussion group [6]. While the PBL model is learning that makes problems as a basis for students to learn where students can apply critical thinking, solve problems and apply knowledge to the real world [7].

In addition to using the right model, teachers can use other innovations that aim to overcome students' problems in understanding abstract concepts, namely the use of analogies. Analogy can help students to visualize structures and processes in chemistry which are mostly difficult things to be sensed and imagined by students or abstract [8].

\section{LITERATURE REVIEW}

\section{A. Model POGIL and PBL}

The POGIL learning model is inquiry learning oriented towards student-centered processes. In the POGIL class, students work in groups (called team learning) which aims to master the concept. Through POGIL students are able to develop skills, high-level thinking, communication, teamwork, management, and assessment and no longer rely on memorization, but develop skills for success in learning [9].

POGIL learning increases students' perceptions of the importance of their peers in helping them to understand concepts. The tasks and roles of heterogeneous group members formed in POGIL activities aim to improve the development of teamwork skills [10]. Students who study in POGIL activities are more coordinated and cooperative in building and understanding concepts well [11]. POGIL classrooms are different from traditional classes teachers only act as facilitators and students take more active roles in learning new concepts [12].

That activities in POGIL are effectively used in learning abstract concepts in students [13]. POGIL learning is carried out by students in small groups with individual roles to ensure that all students are fully involved in the learning process. POGIL depends on the exploration cycle, concept discovery and application [14].
POGIL learning model has a learning cycle with three stages, namely, in the first stage is exploration, where students are required to develop their knowledge through the questions posed by the teacher. The second stage is the discovery of concepts or concept formation, and the final stage is the application or application that students must be able to apply the concepts they already have to solve problems [15].

PBL model can be interpreted as a series of learning activities that emphasize the process of solving problems faced scientifically [16]. In the PBL method, students are required to be able to solve problems in group discussions. All group members exchange ideas about opinions or temporary answers about the problems given by the teacher [17].

PBL is defined as a process or effort to get a solution to a task or situation that is truly real as a problem using rules that are already known [18]. In PBL the focus of learning is on the problem chosen so that learning not only learns concepts related to problems but also scientific methods for solving these problems. Therefore, learning not only must understand the concepts that are relevant to the problem that is the center of attention but also gain learning experiences related to the skills to apply scientific methods in problem solving and foster critical thinking patterns.

PBL is an innovation in learning because in problem-based learning, students' thinking ability is truly optimized through a systematic group or team work process, so that students can empower, hone, test and develop their thinking skills on an ongoing basis. PBL is a way of providing understanding by stimulating students to pay attention, examine and think about a problem to further analyze the problem as an effort to solve the problem [19].

\section{B. Learning outcome}

Learning outcomes are behavioral changes in the form of student or student skills which include: (1) cognitive; (2) attitude; (3) skills. Behavioral change as a result of learning is a change in behavior as a whole, not just one aspect. Learning is not yet complete if it only produces changes in one or two aspects.

\section{Motivation to learn}

Motivation can function as a driver of business and achievement. Someone does something because of motivation. The existence of good motivation in learning will show good results. In other words, with the existence of diligent effort and especially based on the existence of motivation, then someone who learns it can give birth to good achievement. The intensity of motivation of a student will greatly determine the level of learning achievement.

\section{The Influence of Learning Model Oriented Analogy}

Using the right model, the teacher can use other innovations that aim to overcome students' problems in understanding abstract concepts, namely the use of analogies. The use of analogy in the learning process that is carried out appropriately will greatly assist students in understanding the concept, and can help students apply chemistry in their daily lives, and provide visualization to improve students' learning 
motivation. With the existence of POGIL and PBL oriented analogy, students' thinking ability is truly optimized through a systematic group or team work process, so that students can empower, hone, test, and develop their thinking skills on an ongoing basis. With the use of analogies in the learning process, students will more easily understand the learning presented

\section{III.METHODOLOGY}

This research is a quasi-experimental Subjects in this study is a class XI SMAN X 2018/2019 school year, and the object of this research is the influence of chemistry teaching material of Acid and Base. Design in this research can be seen in the following table:

TABLE 1 The research design of the application of the POGIL and PBL oriented analogy is $2 \times 2$ factorial

\begin{tabular}{ccc}
\hline Motivation & \multicolumn{2}{c}{ Leaning Model } \\
\cline { 2 - 3 } & $\begin{array}{c}\text { POGIL oriented } \\
\text { analogi } \\
\left(\mathrm{A}_{1}\right)\end{array}$ & $\begin{array}{c}\text { PBL oriented } \\
\text { analogi } \\
\left(\mathrm{A}_{2}\right)\end{array}$ \\
\hline $\begin{array}{c}\text { High } \\
\left(\mathrm{B}_{1}\right)\end{array}$ & $\mathrm{A}_{1} \mathrm{~B}_{1}$ & $\mathrm{~A}_{2} \mathrm{~B}_{1}$ \\
\hline $\begin{array}{c}\text { Low } \\
\left(\mathrm{B}_{2}\right)\end{array}$ & $\mathrm{A}_{1} \mathrm{~B}_{2}$ & $\mathrm{~A}_{2} \mathrm{~B}_{2}$ \\
\hline
\end{tabular}

Description:

$\mathrm{A}_{1} \mathrm{~B}_{1}$ : The POGIL model is oriented towards the analogy and the level of student motivation is high.

$\mathrm{A}_{1} \mathrm{~B}_{2}$ : The POGIL model is oriented towards the analogy and the level of student motivation is low

$\mathrm{A}_{2} \mathrm{~B}_{1}$ : The PBL model is oriented towards the analogy and the level of student motivation is high

$\mathrm{A}_{2} \mathrm{~B}_{2}$ : The PBL model is oriented towards the analogy and the level of student motivation is high

Some of the variables in the research are independent variable are learning model, analogy, and motivation. The dependent variable learning outcomes. The control variables in this study is the teaching material, namely acid and base and teachers in both classes.

The research procedure is the steps that researchers must carry out in a study in order to obtain good results. The full procedure is presented as follows:

1. Preparing RPP

2. Determine the population and research sample

3. Conducting a pretest of the material taught is the subject of acid bas

4. Do the learning process on the topic of acid base which is divided into: Class I Experiment which is a class that is taught with the POGIL model oriented to the analogy analogy and Class II Experiment that is the class that is taught by PBL model oriented analogy

5. After the learning process ends, each class is given a student learning motivation sheet based on the Likert rating scale.

6. Posttesting students after the learning process is carried out on the subject of acid base. This posttest is done to test students' mastery of acid base material after learning.
7. Processing the data obtained from both learning outcomes and motivation sheets provided

8. Analyze data obtained from research and make conclusions.

\section{RESULTS AND DISCUSSIONS}

Data obtained after doing research in class XI SMAN X on learning acid and base that is result of study result and student learning motivation which is explored with model of POGIL and PBL oriented analogy.

The data of students' learning chemistry result was obtained by using the test result of learning in acid and base learning in the form of pretest and posttest data and then calculated the result of learning in the form of $\mathrm{N}$-gain data. While student learning motivation data is obtained from the motivational questionnaire given at the end of the learning meeting. Students' motivation data are grouped into two, namely high learning motivational data and low learning motivation data.

The sample group that measured the improvement of learning outcomes based on the N-gain value and students' learning motivation were grouped into high learning motivation and low learning motivation based on questionnaire sheets given at the end of the learning meeting.

The hypotheses tested in this study include: 1) There is the influence of the learning model oriented analogy on learning outcomes. 2) There is an effect of the level of student motivation on learning outcomes that are taught by the learning model oriented analogy. 3) There is an interaction between the learning model and learning motivation. Testing hypotheses 1, 2, and 3 using two way variance analysis (ANAVA) technique with Univariate GLM on N-gain data with the help of SPSS 23.0 program. Briefly shown in Table 2.

TABLE 2. Summary of the results of the two-way ANOVA analysis test

\begin{tabular}{cccc} 
Source & Mean & F count. $_{c}$ Sig \\
\hline Learning Model & 0.002 & 0.057 & 0,812 \\
Motivation & 0.345 & 11.34 & 0,001 \\
$\begin{array}{c}\text { Learning } \\
\text { model*Motivation }\end{array}$ & 0.112 & 1.916 & 0,173 \\
\hline
\end{tabular}

Based on Table 2 it can be seen that the learning model applied does not provide the influence shown by the sig value. $\alpha$ is $0.812>0.05$ meaning that $\mathrm{Ha}$ is rejected and Ho is accepted. The level of student motivation to influence students' learning outcomes as shown by the sig $<\alpha$ value of $0.01<0.05$ means that $\mathrm{Ha}$ is accepted and Ho is rejected. The learning model does not have an interaction with the level of motivation in influencing student learning outcomes as shown by $\operatorname{sig}>\alpha$ values that is $0.173>0.05$ meaning that $\mathrm{Ha}$ is rejected and Ho is accepted.

The results of hypothesis testing using two-way ANAVA in Table 2 obtained the value of sig. $>$ A $(0.0812>0.05)$. Thus the hypothesis testing criteria are not met, meaning that $\mathrm{Ha}$ is rejected. Then it can be concluded that the first hypothesis is rejected. This means that there is no effect of the POGIL model oriented on the FAR analogy and the PBL model oriented to the analogy to student learning outcomes. When viewed from the learning outcomes obtained in experimental 
class I with experimental class II, there are differences in learning outcomes that are not much different.

TABLE 3 The results of the average N-gain are based on the results of the learning evaluation in the learning of acids and bases

\begin{tabular}{llcc}
\hline Learning Model & Mean & \multicolumn{2}{c}{ Trust Interval 95\% } \\
\cline { 3 - 4 } & & Low & High \\
\hline $\begin{array}{l}\text { POGIL Oriented } \\
\text { Analogy }\end{array}$ & 0,590 & 0,520 & 0,659 \\
$\begin{array}{l}\text { PBL Oriented } \\
\text { Analogy }\end{array}$ & 0,578 & 0,512 & 0,646 \\
\hline
\end{tabular}

When viewed from the learning outcomes obtained in the experimental class I with experimental class II, there are differences in learning outcomes based on the level of student motivation. Differences in student learning outcomes at the level of sudent learning motivation are presented in Table 4

TABLE 4 The results of the average $\mathrm{N}$-gain are based on students' level of learning motivation (high and low) on learning acids and bases

\begin{tabular}{cccc}
\hline Motivation & Mean & \multicolumn{2}{c}{ Trust Interval 95\% } \\
\cline { 3 - 4 } & & Low & High \\
\hline High & 0.665 & 0.603 & 0.727 \\
Low & 0.502 & 0.427 & 0.577 \\
\hline
\end{tabular}

The data used to determine student learning completeness is the posttest data compared to the KKM values of the chemistry subjects set by the school which is 68. The completeness of learning that is taught by the POGIL and PBL learning models oriented to the analogy with the level of motivation is presented in table 5 .

TABLE 5. Student learning completeness that is taught by learning models with a level of motivation

\begin{tabular}{cccc}
\hline Motivation & \multicolumn{2}{c}{ Nilai rata-rata posttest } \\
& $\begin{array}{c}\text { POGIL oriented } \\
\text { Analogi } \\
\left(\mathrm{A}_{1}\right)\end{array}$ & $\begin{array}{c}\text { PBL oriented } \\
\text { Analogi } \\
\left(\mathrm{A}_{2}\right)\end{array}$ & \\
\hline High & 83,17 (Tuntas) & 80,75 (Tuntas) & 68 \\
$\left(\mathrm{~B}_{1}\right)$ & $\begin{array}{c}\text { K6,80(Tidak } \\
\text { Low }\end{array}$ & $\begin{array}{c}63,33(\text { Tidak } \\
\text { tuntas })\end{array}$ & \\
$\left(\mathrm{B}_{2}\right)$ & & Tuntas $)$ & \\
\hline
\end{tabular}

\section{CONCLUSION}

1. There is no influence between learning model oriented analogy on student learning outcomes.

2. There is an influence between the level of students' motivation that is taught by the learning model oriented analogy of student learning outcomes.
3. There is no interaction between the two learning models with learning motivation towards student learning outcomes. 4. The highest student learning completeness is in the process oriented guided inquiry learning (POGIL) model oriented to the analogy with a high level of learning motivation.

\section{References}

[1] Muhibbin. (2008). Psikologi Pendidikan Dengan Pendekatan Baru. Bandung : Remaja Rosdakarya

[2] Hamalik. (2008). Proses Belajar Mengajar. Jakarta : Bumi aksara

[3] Winarsih. (2009). Psikologi Pendidikan. Medan: Latansa Pers.

[4] Azizah, I. Mulyani, S. dan Khoerunnisa, F. (2016). Development of POGIL (Process Oriented Guided Inquiry Learning) Strategy based on Intertextual Learning of Acid-Base Concepts. Advances in Social Science, Education and Humanities Research (ASSEHR), Vol 57

[5] Sitorus, M. Sudrajat, A. Lestari, M. (2015). Pengembangan Bahan Ajar Inovatif dan Interaktif Melalui Pendekatan Saintifik pada Pembelajaran Reaksi Redoks Dan Elektrokimia. Universitas Negeri Medan. Jurnal Pendidikan Kimia Vol 7, No.2

[6] Gale, S.D dan Boissele, L.N.(2015) .The effect of POGIL on academic performance and Academic Confidence. Science Education International. Vol.26, Isuue 1,2015,56-61

[7] Levine, R. (2009). The Public Poster Session. Canada : Teaching Sociology.

[8] Nufida, B.A. (2013). Model Jembatan Analogi dalam Pembelajaran Kimia untuk Membantu Pemahaman Aspek Mikroskopik Siswa. Jurna Kependidikan, 12 (2): 115-120.

[9] Sri Yani. (2012). Model MFI dan POGIL ditinjau dari Aktivitas Belajar dan Kreativitas Siswa Terhadap Prestasi Belajar. Jurnal Inquiri. ISSN 225-7893, Vol. 1 No,3 (hal 266-275)

[10] Hanson. (2007). Process-Oriented Guided-Inquiry Learning. Pasific Crest

[11] Simonson, S.R dan Shadle, S.E. (2013). Implementing Process Oriented Guided Inquiry Learning in Undergraduate Biomechanics:

[12] Lesson Learned by a Novice . Journal of STEM Education. Vol 14 Isuue 1

[13] Stanford, C., Towns, M., \& Cole, R. (2015). Translating Across Macroscopic, Submicroscopic, and Symbolic Levels: The Role of Instructor Facilitation in an Inquiry-Oriented Physical Chemistry Class. Chemistry Education Research and Practice, 16(4): 769-785.

[14] Watson dan Barthlow. (2011). The Effectiveness of Process Oriented Guided Inquiry Learning to Reduce Altervative Conceptions in Secondary Chemistry. Jurnal of Chemical Education, 114(5), 246-255.

[15] Eberlein, T. Kampmeier, J. Mihderhout, V. Moog, R. S. Platt, T. VarmaNelson, P., dan White, H. B. (2008). Pedagogies of engagement in science: A comparison of PBL, POGIL, and PLTL. Biochemistry and Molecular Biology Education, 36(4), 262-273.

[16] Barthlow, M. J. (2011). The Effectiveness of Process Oriented Guided Inquiry Learning to Reduce Alternate Conceptions in Secondary Chemistry. Disertasi Liberty University

[17] Copriady, J. (2014). Penerapan SPBM yang diintegrasikan dengan Program Exe Learning terhadap Motivasi Hasil Belajar Mahasiswa pada Mata Kuliah Kimia Dasar. Jurnal Pendidikan Kimia. 5(2): 100.

[18] Fadliana, H.N. Redjeki, T. dan Nurhayati, N.D. (2013). Studi Kompetensi Penggunaan Metode PBL dilengkapi Macromedia Flash dan LKS terhadap Prestasi Belajar ditinjau dari Motivasi Siswa pada Materi Asam, Basa dan Garam Kelas VII SMP N 1 Jaten Karanganyar TP 2012/2013, Jurnal Pendidikan Kimia, 2(3): 163.

[19] Arends, R. (2008). Learning to Teach: Belajar untuk Mengajar Buku 2, Terjemahan Soetjipto, P.H dan Soejipt, S.M. Yogyakarta : Pustaka Belajar

[20] Rusman. (2003). Model-ModelPembelajaran. Jakarta: Raja Grafindo. 